\title{
Pericarditis with pericardial effusion complicating chickenpox
}

\author{
D.J. Seddon \\ Guy's Hospital, London SE1 9RT, UK.
}

\begin{abstract}
Summary: A girl with chickenpox is presented. She developed arthritis, pericarditis with pericardial effusion and meningism during the course of her illness. Pericarditis is an unusual complication of this disease, and in this instance was associated with characteristic electrocardiographic changes. Aspects of her case history are discussed.
\end{abstract}

\section{Introduction}

Chickenpox, caused by the varicella virus, is a highly infectious illness most common in children under the age of 10 years. It may be accompanied by a wide variety of manifestations other than the occurrence of fever and a pustular rash.

Arthritis (Priest et al., 1978), and myocarditis (Morales et al., 1971) are reported as complicating this disease, and a case complicated by arthritis and pericarditis with pericardial effusion was described by Williams et al. (1983).

\section{Case history}

A 16 year old girl presented with a four day history of rigors, headache, anterior intermittent chest pain varying on posture, together with pain and swelling related to her right wrist and left ankle. Further enquiry revealed that her younger brother was at home unwell with a fever and a vesicular rash highly suggestive of chickenpox.

Physical examination on admission revealed a very fine pink rash most apparent over her trunk, together with a temperature of $39.4^{\circ} \mathrm{C}$. There was moderate neck stiffness but Kernig's sign was absent. Soft tissue swelling was present over the dorsum of the left wrist, and movement of this joint and also the right ankle was limited by pain. Auscultation of her heart and lungs was normal, and there were no signs to suggest tamponade.

Investigations performed at this stage included a chest X-ray which showed slight globular enlargement of the cardiac silhouette, and an electrocardiogram which demonstrated widespread, upwardly concave

Correspondence: D.J. Seddon, M.A., M.R.C.P., Chest Clinic, Whipps Cross Hospital, London E11, UK.

Accepted: 9 July 1986
ST segment elevation (Figure 1). Blood count showed haemoglobin $11.1 \mathrm{~g} / \mathrm{dl}$ white cell count $10.1 \times 10^{9} / 1$, with a normal differential, platelets $140 \times 10^{9} / 1$. Lumbar puncture was normal. M-mode echocardiography demonstrated the presence of a small pericardial effusion.

Within 4 days she developed a centripetal vesicular rash and at this time she was also noted to have a pericardial rub. There was still no evidence of cardiac tamponade. With the use of immunofluorescence techniques, varicella was subsequently demonstrated as being present in the fluid contained within the pustules.

Without specific treatment her fever rapidly subsided and within one week her arthropathy had remitted. The pericardial rub vanished within 48 hours of its detection. The appearance of serial electrocardiograms returned to normal within one week.

Six weeks following discharge from hospital, she remains quite well.

\section{Discussion}

Herpes viruses are double-stranded DNA viruses characteristically dependent upon their hosts. There are four types of herpes infection in which the host is human. The causative viruses are herpes simplex, cytomegalovirus, Epstein-Barr virus and varicellazoster.

Chickenpox caused by varicella can be a severe and debilitating illness, particularly in the adult patient. When associated with neurological or pulmonary involvement there may be considerable morbidity and even mortality (Fleischer et al., 1981; Plotkin, 1985).

Arthritis is well recorded as complicating varicella infection and may be either monoarticular, or polyarticular and asymmetrical (Mulhearn et al., 1978; Ward \& Bishop, 1970; Diliberti et al., 1977).

(C) The Fellowship of Postgraduate Medicine, 1986 


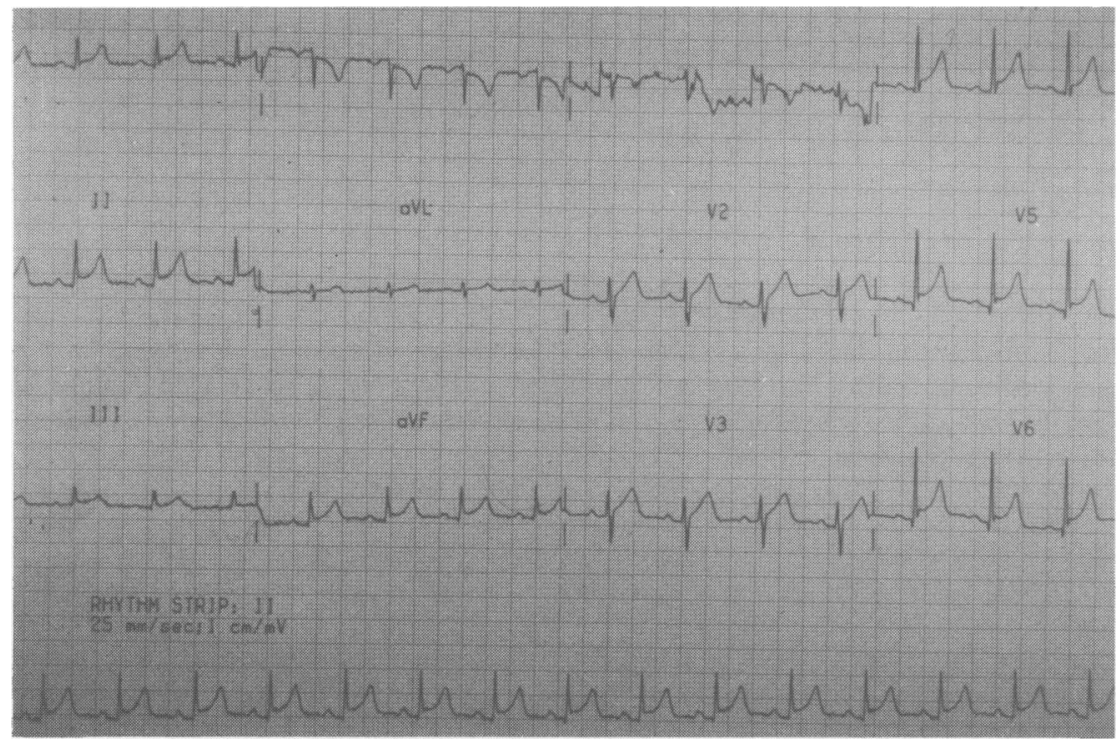

Figure 1 Electrocardiogram showing widespread concave ST segment elevation.

Carditis however is an infrequent complication. This case suggests that pericarditis with pericardial effusion should be regarded as a complication of chickenpox, and that furthermore, the electrocar- diographic changes of pericarditis can be expected to occur. A case previously described, where chickenpox was associated with pericardial effusion, was not associated with such changes (Williams et al., 1983)

\section{References}

DILIBERTI, J.H., BARTEL, S.J., HUMPHREY, T.R. \& PANG, A.W. (1977). Acute monoarticular arthritis in association with varicella. Clinical Pediatrics, 16, 663.

FLEISHER, G., HENRY, W., MCSORLEY, M., ARBETER, A. \& PLOTKIN, S. (1981). Life-threatening complications of varicella. American Journal of Diseases of Children, 135, 896.

MORALES, A., ADELMAN, S. \& FINE, G. (1971). Varicella myocarditis. Archives of Pathology, 91, 29.

MULHEARN, L.M., FRIDAY, G.A. \& PERRI, J.A. (1978). Arthritis complicating varicella infection. Pediatrics, 48, 827.
PLOTKIN, A. (1985). Clinical and pathogenic aspects of varicella-zoster. Postgraduate Medical Journal, 61, (Suppl 4), 7.

PRIEST, J.R., URICK, J.J., GROTH, K.E. \& BALFOUR, H.H. (1978). Varicella arthritis documented by isolation of virus from joint fluid. Journal of Pediatrics, 93, 990.

WARD, J.A. \& BISHOP, B. (1970). Varicella arthritis. Journal of the American Medical Association, 212, 1954.

WILLIAMS, A.J., FREEMONT, A.J. \& BARNETT, D.B. (1983). Pericarditis and arthritis complicating chickenpox. British Journal of Clinical Practice, 37, 226. 